\title{
Variations of Incident Solar Flux and Snow Albedo on the Solar Zenith Angle and Cloud Cover, at Mizuho Station, Antarctica
}

\author{
By Takashi Yamanouchi \\ National Institute of Polar Research, 9-10 Kaga 1-chome, Itabashi-ku, \\ Tokyo 173, Japan \\ (Manuscript received 7 June 1983, in revised form 3 October 1983)
}

\begin{abstract}
The broad band spectral measurements of the incident and reflected shortwave radiation were carried out on the snow cover at Mizuho Station, East Antarctica under the POLEXSouth program during 1979 and 1981. Diurnal, daily and seasonal variations of both the global solar radiation and albedo were analyzed against two spectral regions, solar zenith angle and cloud cover, with a special intention to the interaction between the global radiation and albedo.

The global radiation was large compared to that at the normal mid-latitude station. The atmospheric transmittance was high about 0.75 to 0.80 in the average in summer months because of small amount of atmospheric molecules, aerosols and water vanor. The diffuse radiation from a clear sky, which was similar to the Rayleigh scattering, was about twice as large as that for the place of $0 \%$ albedo owing to the high surface albedo through the multiple reflection between the snow surface and atmospheric layer. The effect of clouds to reduce the global radiation was small also on account of the multiple reflection, especially in the visible spectral region. The effect of drifting snow was also examined.

The snow albedo for the clear sky was about 0.8 on the daily average in the total wavelength region of the solar radiation. The albedo was higher than 0.95 in the visible region and about 0.66 in the near infrared under the clear sky. The cloudy sky albedo was higher than the clear sky albedo on account of the variation of spectral distribution of the incident solar flux. The solar zenith angle dependence of the albedo was various owing to the micro and macroscale snow surface conditions, however, mostly the albedo became high when the solar elevation became low. The measured albedo was compared to the theoretical albedo calculated from a radiative transfer model, and a good accordance was found on the average.
\end{abstract}

\section{Introduction}

The properties of solar radiation over the Antarctic snow field, which is strongly affected by the snow surface albedo, is one of the controlling factors of the surface energy budget. The long duration of sunshine in summer, no solar radiation in winter and low solar elevation on the average characterize the solar radiation. High snow albedo makes the input radiative energy small and causes the Antarctic to be a heat sink in the global scale.

Several works on the radiation properties over the Antarctic snow field were made since the pioneering study by Liljequist (1956) who made an analysis based on the measurement done at Maudheim Station during Norwegian-BritishSwedish Antarctic Expedition, 1949-52. His detailed evaluation of calibration factors and careful analysis of radiation budget have been a model guide to the later radiation measurements in the Antarctic. During the IGY, radiation measurement had been carried out at many stations over the Antarctic Continent and the results were compiled by Hanson (1960), Rusin (1964) and Dalrymple (1966). Weller (1967) had described the detailed properties of radiation flux at Mawson Station, and Kuhn et al. 
(1977) had made an extensive report on the radiation budget at Plateau Station obtained from the micrometeorological program, 19661968. By the Japanese Antarctic Research Expedition, radiation measurements had been made at Syowa and Mizuho Stations, however, only a few results were analyzed by Kawaguchi and Sasaki (1975) yet, who posed several essential problems to the properties of the shortwave radiation at Mizuho.

Recently, Wiscombe and Warren (1980) and Choudhury and Chang (1981) made theoretical calculations of the snow albedo based on the radiative transfer model. One of their intension was to explain the spectral dependence of albedo of the natural snow surface over the Antarctic and Arctic, just as measured by Kuhn and Siogas (1978) and Grenfell and Maykut (1977). Their calculated albedos in the visible region were much higher than measured albedo by Kuhn and Siogas. The incident angle dependence of the albedo was measured by Carroll and Fitch (1981) at the South Pole. However, the dependence was quite steeper than the calculated dependence by Wiscombe and Warren (Warren, 1982). The question is left what is the incident angle dependence of the snow albedo.

The total albedo which is a weighted mean of spectral albedo with the incident solar flux has strong dependence on the spectral distribution of the incident solar flux. The incident solar flux also depends strongly on the surface spectral albedo through the multiple reflection of solar flux between the snow surface and the atmospheric layer. So the both components, albedo and incident flux cannot be discussed independently, and should be examined from the view point of interaction between each others.

In the present paper, the incident solar flux is discussed together with the snow albedo from the observational results of 1979 . The observation was made within the frame work of the Japanese Polar Experiment (POLEX-South) (Kusunoki, 1981) at Mizuho Station $\left(70^{\circ} 42^{\prime} \mathrm{S}, 4^{\circ}\right.$ 20'E), East Antarctica from 1979 to 1981 by the Japanese Antarctica Research Expedition. As shown in the map of Fig. 1, Mizuho Station is located at the height of $2230 \mathrm{~m}$ above sea level on the slope of the Antarctic Continent. The climate of Mizuho is characterized mainly by the extensive and permanent snow cover, katabatic wind which blows continuously at the speed of about $10 \mathrm{~m} / \mathrm{s}$ and strong surface tem-

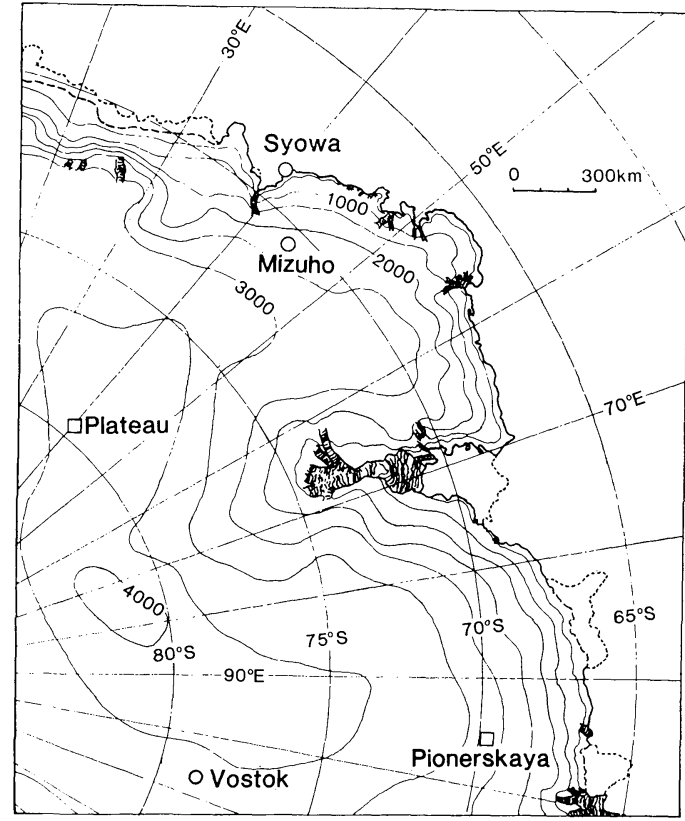

Fig. 1 Location of Mizuho Station in East Antarctica.

perature inversion. General descriptions of the properties of the surface radiation budget at Mizuho Station were already made by Yamanouchi et al. (1982) and Ishikawa et al. (1982).

\section{Measurements}

The global and reflected shortwave radiation were measured by Eko-MS800 pyranometers set at the height of $1.5 \mathrm{~m}$ above the snow surface and at the top of a $30 \mathrm{~m}$ tower. The direct solar radiation was also measured by EkoMS52F pyrheliometer set on the equatorial at the height of $1.5 \mathrm{~m}$. Spectral measurements of shortwave radiation divided in four wavelength intervals were carried out using cut-off filters; $305-2800 \mathrm{~nm}$ with the filter of WG305 (no filter but only with a quartz window for the pyrheliometer), $530-2800 \mathrm{~nm}$ with OG530, 630$2800 \mathrm{~nm}$ with RG630, and 695-2800 nm with RG695, respectively (each filter for each pyranometer and one rotating filter disk for pyrheliometer). Shading plates were set around the down facing pyranometers which measured the reflected radiation in order to cut the undesirable direct solar beam to illuminate horizontally the hemispheric filter dome and to contaminate the measurements in the case of low solar elevation. The output signals of radiometers were sampled every minute and recorded on 
computer compatible magnetic tapes and on the analogue recorder as a monitor.

Calibrations of the sensors should be made carefully in order to make a precise radiation measurement. Especially in order to derive the incident angle dependence of radiation fluxes, it was indispensable to assure the incident angle dependence of the sensitivity constant of pyranometers. The field calibrations of the pyranometers were made by the sun occulting (shading disk) method in comparison with the pyrheliometer. The calibration factor $K(h)$ defined as a ratio of the measured to the true radiation flux was obtained as Fig. 2 for an example. $K(h)$ shows the deviation from the cosine law response.

Another calibration factor applicable to the diffuse radiation was determined. The factor $F_{I}$ for the isotropic diffuse radiation (radiance $I_{1}$ ) was obtained by integrating $K(h)$ over the incident angle as

$$
\begin{aligned}
F_{I} & =\int_{0}^{\pi / 2} 2 \pi K(h) I_{1} \sin h \cos h d h / \pi I_{1} \\
& =\int_{0}^{\pi / 2} K(h) \sin 2 h d h .
\end{aligned}
$$

$F_{I}$ was applied for the reflected radiation from the snow surface and the radiation from clouds which was assumed to be isotropic. For the anisotropy of sky radiation, the intensity was simply assumed to increase toward the horizon proportionally to the number of diffusing particles present; i.e., proportional to the air mass $m=1 / \sin h$ (Liljequist, 1956; Weller, 1967; Kuhn et al., 1977; Coulson, 1975). The calibration

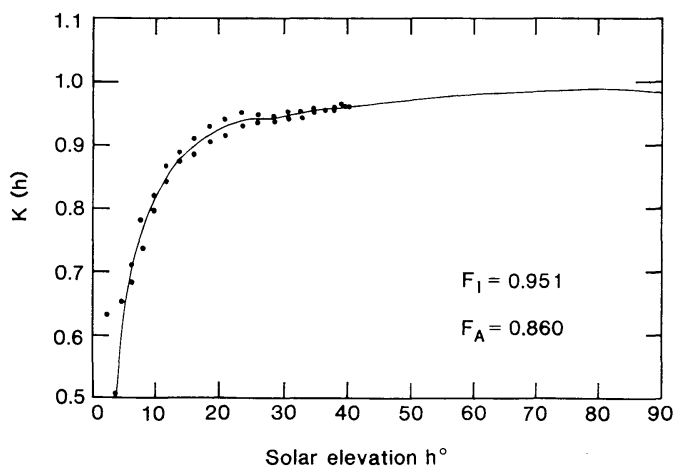

Fig. 2 Incident angle dependence of calibration factor $K(h)$ of the pyranometer Eko MS-800, No. F78510. Points represent the field calibrations. Solid line for $h>40^{\circ}$ was obtained from the laboratory measurement. factor $F_{A}$ for the clear sky radiation was derived as

$$
F_{A}=\int_{0}^{\pi / 2} K(h) \cos h d h .
$$

In the case of partly cloudy sky, a new calibration factor was applied, which was derived from $K(h), F_{A}$ and $F_{I}$ according to the ratio of clear and cloudy sky (cloud amount). Because the cloud amount was observed only 6 hourly by the eye and not recorded continuously, an approximate clear sky index $C_{C}=I(h) / I_{S}(h)$ was substituted for it, where $I_{\mathrm{S}}(h)$ was a typical direct solar flux at the surface of Mizuho under the clear sky with the solar height $h$ and $I(h)$ was an actual direct flux. In spite of crude treatment, it would be appropriate because the derivation of data was restricted only to the mean value of 30 minutes in the present study. The temperature dependence of the sensitivity constant of pyranometers was included implicitly in the calibration constant $K(h)$.

The pyrheliometer itself had been once calibrated by the Japan Meteorological Agency at about $20^{\circ} \mathrm{C}$. In the field at Mizuho Station, it was occasionally calibrated against Eppley Ångström absolute pyrheliometer standardized by IPS-1956, by which whole the system was standardized. The temperature coefficient of the sensitivity was obtained as $-0.13 \% /{ }^{\circ} \mathrm{C}$.

As for the reflected solar flux, an influence of shadows of the instruments and holding pipes on the snow surface was corrected, which amounted to 3 to $5 \%$ of the reflected flux for the direct solar radiation according to the solar elevation.

During the period of investigation, a frost occasionally deposited on the filter dome, and the frost was removed by means of cloth or a wood strip. The instruments had to be surveyed several times a day.

The experimental accuracy of pyranometer measurements of 30 minutes average was estimated normally to be $\pm 1-3 \%$ from the scattering of points, which sometimes means the azimuth dependence, in the determination of calibration curve for the solar height $h>5^{\circ}$ (Yamanouchi et al. 1981a; and Fig. 2). The actual experimental uncertainties are shown by error bars in the figures for the typical value. The installation and performance of the system of measurements and recordings were previously reported by Mae et al. (1981), calibrations of the sensors were mentioned in detail by Yama- 
nouchi et al. (1981b) and the hourly radiation fluxes were compiled in the data report (Yamanouchi et al., 1981a).

\section{Global radiation under clear sky}

The seasonal trend of daily average of global radiation $(G)$ under a clear sky (cloud amount $0 / 10$ ) is examined. The global radiation for clear sky increases monotonously from zero in winter to the maximum in December $\left(442 \mathrm{~W} / \mathrm{m}^{2}\right.$ on December 22). These summer months correspond to the season when the sun-earth distance is shortest.

In order to see the effect of atmosphere, the effective transmittance defined as $\bar{G} / \overline{I_{0} \sin h}$ (bar is for daily average) is calculated and shown in Fig. 3, where the solar constant $I_{0}$ is assumed as $1353 \mathrm{~W} / \mathrm{m}^{2}$ (Thekaekara and Drummond, 1971). For clear days, it is about $85 \%$ in summer months (February, November and December), and small in the other months. The high transmittance in spring side and low transmittance in fall side for clear days as pointed out by Kuhn et al. (1977) from the measurements at Plateau Station are not seen in the present results. However, the average transmittance for whole days in a month tends to be higher in spring side and lower in fall side, which simply reflects the difference in cloudiness in both seasons. The monthly average transmittance is 0.75 in February, 0.71 in March, 0.55 in April, 0.67 in September, 0.77 in October, 0.78 in November, and 0.81 in December. The annual average (Feb. 18-Dec. 31) is 0.757, which is larger than 0.73 at Pionerskaya and smaller than the typical
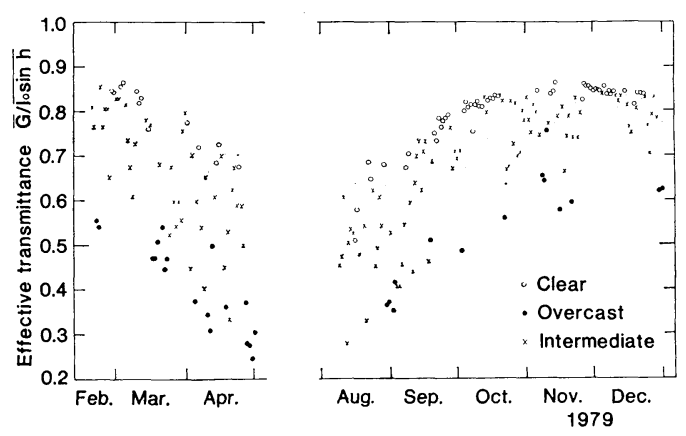

Fig. 3 Seasonal variation of effective transmittance of atmosphere defined as $\bar{G} / \overline{I_{0} \sin h}$. Extraterrestrial radiation $I_{0}$ is assumed as $1353 \mathrm{~W} / \mathrm{m}^{2}$. Clear (cloud amount $0 / 10$ ), overcast (only for middle and low clouds, cloud amount 10/10) and intermediate (rest of clear and overcast). transmittance on the Antarctic Plateau, 0.80 (Kuhn et al., 1977). This is mainly due to the difference in cloud amount.

The dependence of global radiation in the clear sky on the solar zenith angle (solar height: $h)$ is shown in Fig. 4 as a function of $\mu_{0}=\sin h$. The plotted values are 30 minutes averages of measured value corrected for the mean sunearth distance, about 50 clear days throughout an year. The extraterrestrial solar radiation $I_{0}$ $\sin h$ is also illustrated by a solid line. Scatterings of points are quite small. The global radiation $G(h)$ in the region $\sin h \geq 0.05$ can be approximated by the curve fitted by least-squares analysis similar to that of Paltridge and Platt (1976) as

$$
G(h)=29.7-298 \sqrt{\sin h}+1542 \sin h .
$$

The standard deviation of points is $5\left(\mathrm{~W} / \mathrm{m}^{2}\right)$. If the fitting was made for each month, variations were less than about $1 \%$. For example, the global fluxes for $h=30^{\circ}$ by respective curves are $591,593,586 \mathrm{~W} / \mathrm{m}^{2}$ for October, November and December, respectively. The horizontal component of the direct solar radiation is also approximated by the same type of formula as

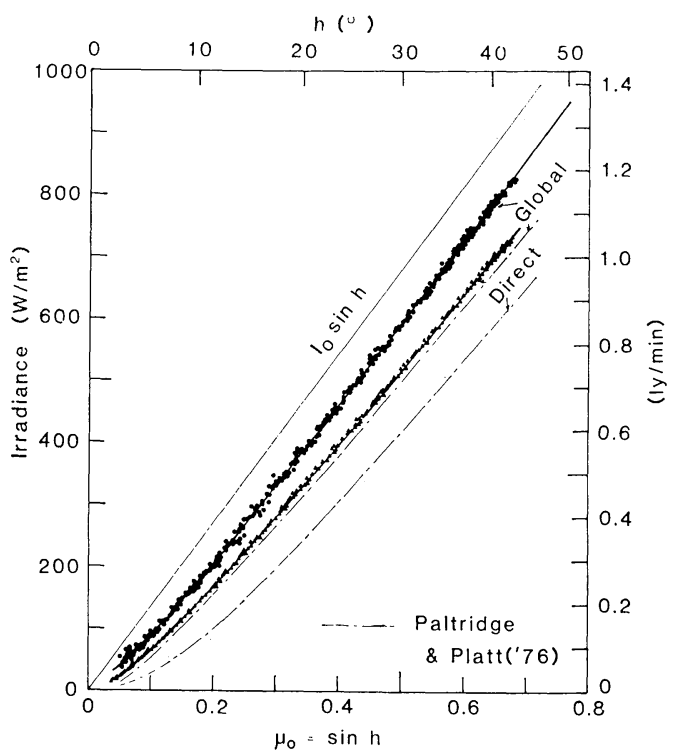

Fig. 4 Dependence of global and direct radiation (30 minutes average) on solar elevation angle under clear sky (cloud amount $0 / 10)$ as a function of $\mu_{0}=\sin h$. Thick solid lines are empirical fits, Eqs. (3) and (4) for global and direct radiation, respectively. 
$I(h) \sin h=24.2-328 \sqrt{\sin h}+1449 \sin h$,

with the standard deviation $2.5\left(\mathrm{~W} / \mathrm{m}^{2}\right)$.

In order to compare the global radiation, one of the typical results of mid-latitude from the text of Paltridge and Platt (1976) which were measured at Aspendale, Australia is shown. It was reported that Aspendale had an annual mean atmospheric water content of $1.5 \mathrm{~cm}$ and an annual mean aerosol optical depth at $500 \mathrm{~nm}$ of $0.1 \pm 20 \%$. The curve shown in Fig. 4 is their empirical curve. The global radiation at Mizuho is quite large for the same solar elevation compared to the value at Aspendale, and much close to the extraterrestrial value. This is because the density of atmospheric molecules is low on account of the high altitude of the station $(2230 \mathrm{~m})$, the amount of aerosols is small (aerosol optical depth at $500 \mathrm{~nm}$ was less than 0.02; Yamanouchi, 1982) and the atmospheric water content is also small (about $0.15 \mathrm{~g} / \mathrm{cm}^{2}$ in summer season; Yamanouchi and Wada, 1981), just as speculated by Kawaguchi and Sasaki (1975). This is also confirmed by the comparison of the direct radiation (horizontal component). The depletion of direct radiation is also small at Mizuho. It can be said that this atmosphere is rather similar to the Rayleigh atmosphere. It was pointed out by Warren and Wiscombe (1982) that the solar absorption due to $\mathrm{CO}_{2}$ and Ozone would be enhanced by the lack of water vapor, and then, the radiation

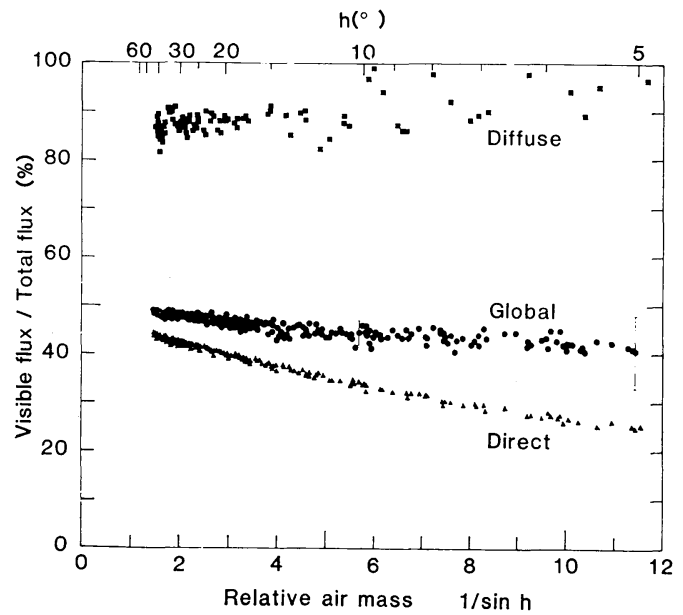

Fig. 5 Ratios of visible flux to total solar flux for direct $(I)$, global $(G)$ and diffuse $(D)$ radiation under clear sky, as a function of relative air mass $1 / \sin h$. budget might be more sensitive to $\mathrm{CO}_{2}$ variations in the Antarctic than elsewhere.

From the filter measurements, downward fluxes for two spectral region-VIS (305-695 $\mathrm{nm})$ and IR (695-2800 nm)-are derived. Fig. 5 shows the ratio of the visible flux to the total flux $(305-2800 \mathrm{~nm})$ as a function of relative air mass $m$. The variation of the ratio of visible global flux on the air mass mainly follows that of direct flux. As for the direct radiation, the visible flux is depleted due to the scattering much more than the infrared flux which is depleted due to water vapor and $\mathrm{CO}_{2}$ absorption according to the increase of the air mass. A few differences in the tendencies of the global and direct radiation are brought on by the diffuse component, which will be discussed in the next section. The extrapolated value of both the ratio of global and direct radiation to 0 of air mass seems to be about $50 \%$.

\section{Diffuse radiation under clear sky}

Fig. 6 shows the variation of diffuse flux on the solar elevation. The diffuse flux is derived from subtracting the horizontal component of direct flux from the global flux as

$$
D=G-I \sin h \text {. }
$$

It should be kept in mind that the diffuse component in this work means the diffuse flux coming from the sky without the disk of radius of 4 degrees around the solar point.

It is found that the diffuse components at Mizuho are extremely large, just as comparable to those at Aspendale (Paltridge and Platt, 1976), in spite of the small depletion of the direct

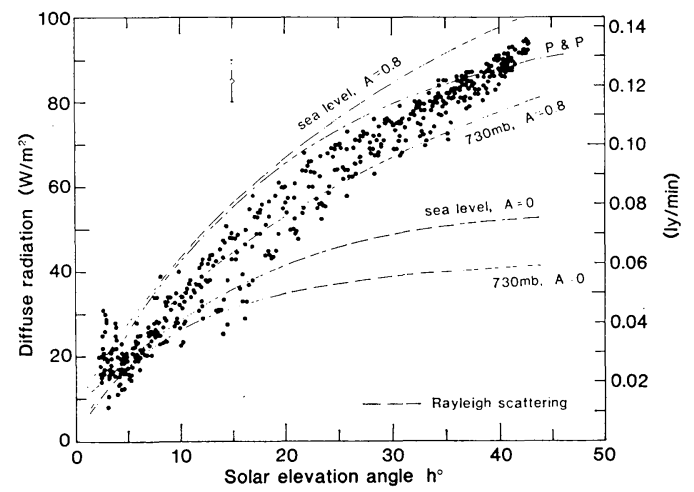

Fig. 6 Variation of diffuse flux $(D)$ on solar elevation angle $h$. Broken lines for Rayleigh scattering calculated from the data by Coulson (1968). Dashed-dotted line is by Paltridge and Platt (1976). 
component mentioned in the last section. The low density of atmospheric molecules and small amount of aerosols would result in the small diffuse radiation. However, the high surface albedo about $80 \%$ makes the diffuse radiation large on account of multiple reflection between the snow surface and the atmospheric layer (Liljequist, 1956; Weller, 1967). This situation is clearly explained by the calculated curves for the Rayleigh scattering. The calculation is based on the results of Coulson (1968), but for $730 \mathrm{mb}$ of the surface pressure, the spectral distribution of the extraterrestrial solar flux by Thekaekara and Drummond (1971) and Rayleight optical depth by Fröhlich and Shaw (1980). On account of multiple reflections, the diffuse flux by Rayleigh scattering for $80 \%$ surface albedo increases twice as large as that for $0 \%$ albedo. The present results are still more larger than the Rayleigh scattering for $80 \%$ surface albedo. Though not certified quantitatively, this is owing partly to the Mie scattering by aerosol particles and partly to the difference in surface albedo for the visible and near infrared as shown in the later section; the albedo is high in the visible region, where the Rayleigh scattering is much effective. It is important to know the spectral albedo for the analysis of incident flux.

Looking in detail there is another tendency that the curves for high albedo, regardless of measured or calculated, are still increasing rapidly around 30 or 40 degrees of the solar height, though the curves for low albedo seem to be saturated. Considering the results of model calculation by Coulson (1968), the skylight which is the whole component of the diffuse flux for $0 \%$ albedo is rather constant against the incident angle variation except for the low solar height or large optical depth. Whereas, in the case of high albedo, the diffuse flux is composed of the skylight without surface reflection and skylight multiple reflected by the surface. The latter increases according to the direct flux $I \sin h ;$ i.e., nearly proportional to $\mu_{0}=$ $\sin h$.

The ratios of diffuse flux to the global flux are estimated and plotted on Fig. 7 for the total solar wavelength region $(305-2800 \mathrm{~nm})$, visible $(305-695 \mathrm{~nm})$ and infrared $(695-2800 \mathrm{~nm})$, respectively, as a function of the relative air mass. The ratio at Plateau Station which is given as a straight line by Kuhn et $a$. (1977) is compared. In the region of small air mass, the present result is slightly larger than the ratio

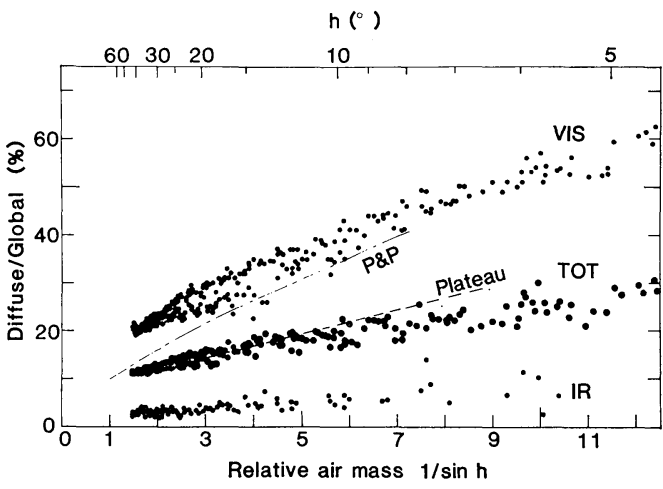

Fig. 7 Ratio of diffuse flux $(D)$ to global flux $(G)$ as a function of relative air mass, for total (TOT), visible (VIS) and near infrared (IR) solar radiation. Dashed-dotted line is by Paltridge and Platt (1976).

at Plateau just as expected from the difference in elevation of stations (Plateau Station: $3630 \mathrm{~m}$ ). However, in the region of air mass larger than 5 , the situation is contrary. This fact may be due to the straight line approximation of the ratio at Plateau. The ratio of diffuse flux at Aspendale for the total is also shown in the figure from the same origins mentioned above. In spite of similar amount of diffuse flux itself, the ratio is much greater than the present on account of small global radiation.

As shown in Fig. 7, in the visible region, the ratio of diffuse component is large and increases greatly when the air mass becomes large. On the other hand, in the near infrared region, the ratio of diffuse component is quite small and increases very slowly according to the air mass. From these two results and also from the ratio of visible component in the global radiation in Fig. 5, the ratio of visible component in the diffuse radiation can be expected to increase according to the air mass, which is just shown in the upper part of Fig. 5. It is clear in Fig. 5 that the large portion of the diffuse flux comes in the visible region. In the case of pure Rayleigh atmosphere (no absorption), the situation is more pronounced and the visible component in the diffuse flux will be more than $90 \%$ $\left(h>10^{\circ}\right)$.

\section{Global radiation under cloudy sky}

In order to see the primary effect of clouds on the global radiation, we analyzed the results of only four days (November and December) which were overcasted with the thickest clouds observed at Mizuho Station (we assumed as 
altostratus: As, 10/10). Otherwise, the effects of clouds on the global radiation are so diversed due to the kinds of clouds, cloud amounts and cloud distributions that it is very difficult to find out a general effect. So these results can be considered as the largest contribution by clouds at Mizuho.

Thirty minutes averages of the global radiation under overcast sky are shown in Fig. 8 as a function of $\mu_{0}$ with the single curve for the clear sky which is obtained from Fig. 4. Though these are the thickest clouds at Mizuho, the reduction of global radiation is small and about $30 \%$ near $\mu_{0}=0.5$. It is difficult to compare strictly with other results because there are no informations about the cloud thickness except that the solar disc could not be discerned through the clouds. However, simple comparison with the data of As $(10 / 10)$ by Kondratyev (1969) is made. His data was derived from the surface measurements at Pavlofsk (in the suburbs of Leningrad, U.S.S.R.) where the surface conditions was normal just as grass field. The diminution by clouds was very large.

There should be some doubt that the clouds at Mizuho are thinner than those at Pavlofsk (for these cases at Mizuho, the brightness temperature of the bottom of clouds was about $-19 \sim-23^{\circ} \mathrm{C}$ and it was supposed to be water clouds). However, though the radiative properties of clouds are the same, this difference can be explained by the multiple reflection by the earth's surface and cloud layer, similar to the case of the diffuse radiation under the clear sky, also pointed out by Kawaguchi and Sasaki (1975), Wendler et al. (1981), and Choudhury and Chang (1981). The effective transmittance of cloud $\tau_{c}$ can be expressed as

$$
\tau_{c}=\frac{G \text { (overcast) }}{G \text { (clear) }}=\frac{T}{1-a R},
$$

where $a$ is the surface albedo, $T$ and $R$ are the transmittance and reflectance (bottom) of clouds respectively and the effect of atmospheric absorption between the surface and cloud base is neglected (Wendler et al., 1981; Wiscombe, 1975). Assuming the surface albedo to be 0.8 at Mizuho Station and 0.15 at Pavrofsk, and clouds to be same at both places, and if we give $\tau_{c}$ to be 0.67 at Mizuho and 0.36 at Pavrofsk (values at $\mu_{0}=0.5$ ), then $T$ and $R$ will be solved as 0.33 and 0.63 , respectively. These values lie between the results for two model clouds "As" and "St" by Liou (1976), who made

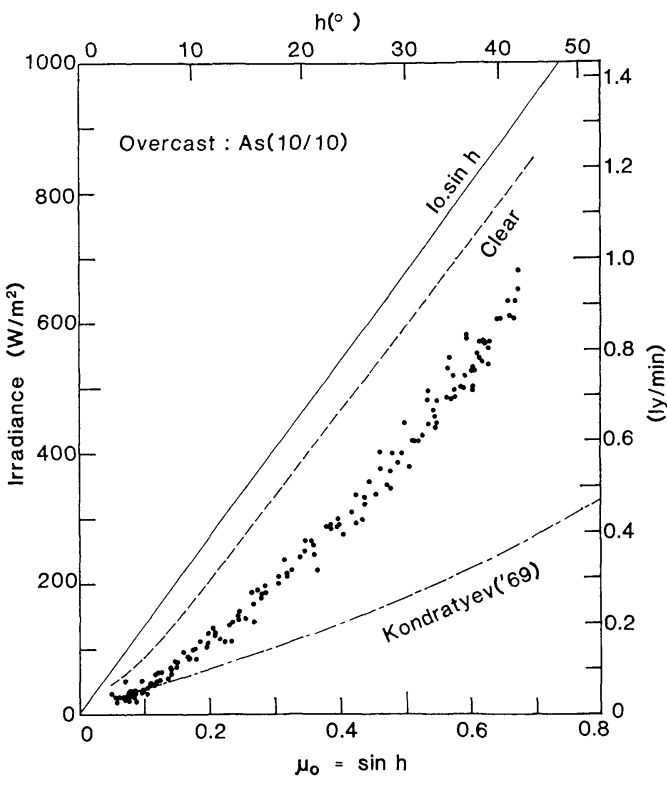

Fig. 8 Global radiation under overcast sky (middle or low cloud, cloud amount 10/10) as a function of $\mu_{0}=\sin h$. Dashed line for clear sky is Eq. (3), and dashed-dotted line is from Kondratyev (1969).

a radiative transfer calculation for cloud models and obtained $T$ as 0.20 and 0.36 and $R$ as 0.67 and 0.60 , respectively for two models. So it is not unrealistic to explain the difference in Fig. 8 by an influence of the surface albedo. On account of this multiple reflection effect, the depletion of global radiation by cloud is small and just we see in Fig. 3, overall transmittance does not go down so much. The monthly average transmittances are all above $70 \%$ from October to March.

The global radiations under the overcast sky in the visible and near infrared spectral regions are shown in Fig. 9, compared to those under the clear sky. In the visible region, the depletion of global radiation is very small on account of small absorption caused by clouds. On the other hand, in the near infrared, on account of the strong absorption by cloud droplets and water vapor in the cloud, the depletion of global radiation is larger instead of multiple reflection effects. It is apparent from this figure that the most part of attenuation - absorption - of the global radiation by clouds occurred in the near infrared region. This situation is also pronounced by the difference in multiple reflection effect owing to the spectral difference of surface albedo 


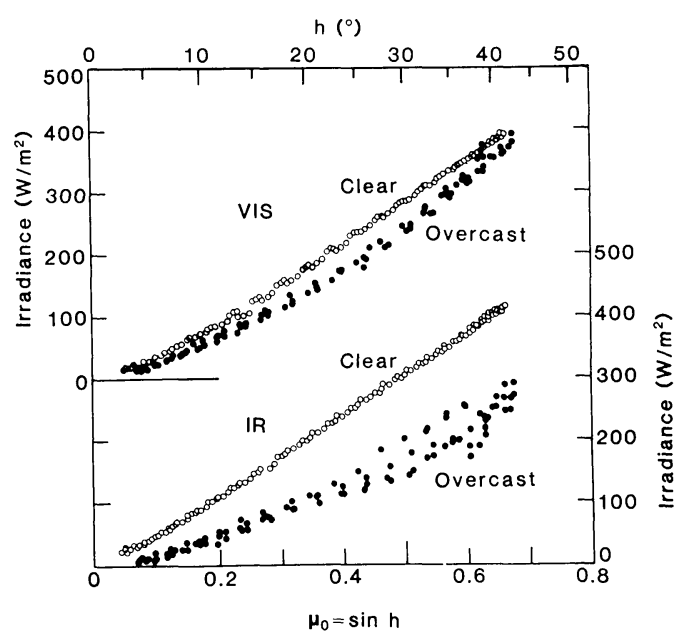

Fig. 9 Global radiation in visible (VIS) and near infrared (IR) spectral region as a function of $\mu_{0}=\sin h$, for clear (cloud amount $0 / 10$ ) and overcast (middle or low cloud, cloud amount 10/10).

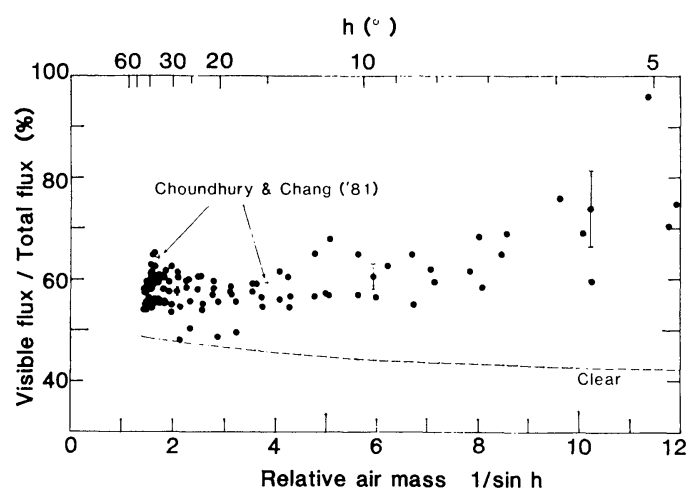

Fig. 10 Ratio of visible global flux to total global flux under overcast sky as a function of relative air mass $1 / \sin h$. Broken line for clear sky is from Fig. 5.

discussed in the next section.

Again, in order to see the spectral distribution of the global radiation under the overcast sky, the ratio of the visible flux to the total flux is shown as a function of the relative air mass in Fig. 10. The plotted points diverse greatly, and it is not easy to derive a precise relation, however, the ratio tends to increase slowly against the air mass increase. The ratio under the overcast sky is apparently larger than that under the clear sky.

It is said that the drifting snow, which is occasionally strong at Mizuho Station, also affects the radiation flux. Because the effect of drifting snow on the global radiation is difficult to distinguish from the effect of clouds from a single measurement, the global radiation was tried to be measured also at the top of a $30 \mathrm{~m}$ tower. From the statistical work by Ishikawa et al. (1982), the correlation between the global radiations measured at two sites was very high and the overall influence of the drifting snow was not so apparent. From a few case studies, the largest depletion of the direct flux up to $50 \%$ is found on November 23 (air mass $\leq 5$ ) when the wind speed is about $17 \mathrm{~m} / \mathrm{s}$ and the visibility is around $0.1 \sim 0.3 \mathrm{~km}$. However, at the time, the diffuse flux increases about four times as that for the normal clear sky, and the effect on the global flux is almost compensated. Only about 5\% depletion is seen for the global flux measured at $1.5 \mathrm{~m}$ height. The global flux measured at $30 \mathrm{~m}$ height is about $3 \sim 4 \%$ larger than that at $1.5 \mathrm{~m}$ in this case. Since we had no quantitative information of the drifting snow this year the quantitative relation between the drifting snow and radiation flux was still left for the future analysis.

\section{Daily values of snow albedo}

Daily values of albedo, defined as the ratio of the daily average reflected shortwave radiation $\bar{U}$ to the daily average global radiation $\bar{G}$ as

$$
a=\bar{U} / \bar{G},
$$

are shown in Fig. 11. The figure is composed of three spectral regions; a) total $(305-2800 \mathrm{~nm})$, b) visible $(305-695 \mathrm{~nm})$, and c) near infrared $(695-2800 \mathrm{~nm})$, and data points are classified in three types according to the cloud amounts. In Fig. 11(a), the albedo under clear sky shows fairly constant value just about 0.8 from October to December. The annual average is 0.805 \pm 0.009 . Points in September diverse greatly, however, some are unreliable because of troubles occurred in the measurement system. No apparent seasonal variations are seen as a dependence on solar elevation or an evidence of the change of snow surface condition, e.g., metamorphosis. As will be discussed later, on account of large diurnal variations, it is difficult to consider the variation of albedo in detail by the daily average values. From this figure, it is found that the albedo for the cloudy sky is higher than that for the clear sky and the average for the overcast with the thick cloud 

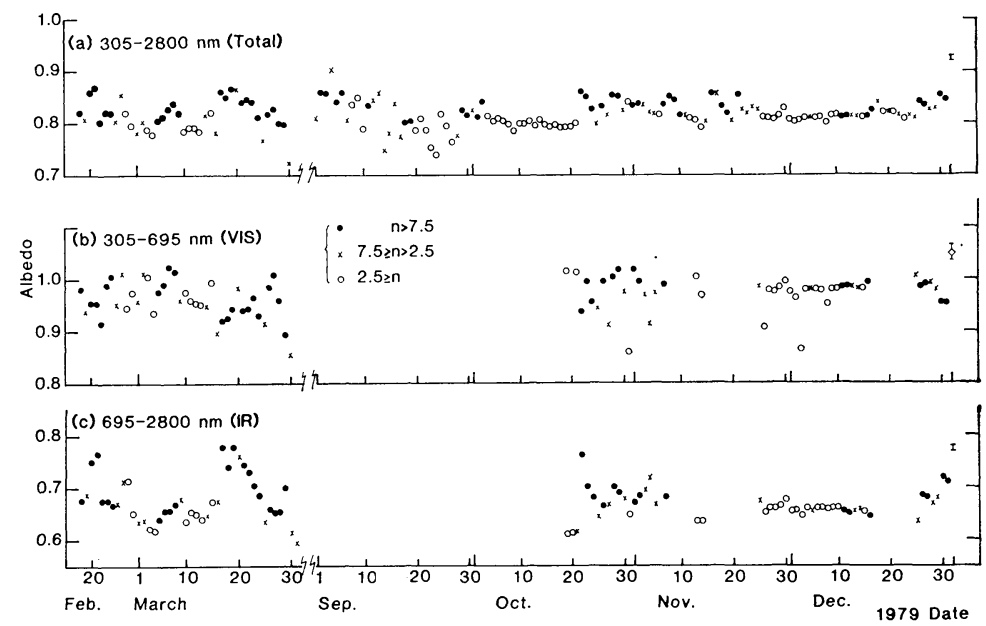

Fig. 11 Seasonal variation of daily values of albedo for (a) total, (b) visible and (c) near infrared spectral regions. Points are distinguished by daily average cloud amounts $n$.

is $0.85 \pm 0.01$.

Comparing Fig. 11(b) and (c), the difference of albedo in two spectral regions can be found. In the visible region, experimental uncertainties become large, because these values are obtained from the data by four independent pyranometers, and some points show larger than 1.0. However, most of points lie between 0.93 and 1.0, and the average is $0.963 \pm 0.037$. On the other hand, the albedo in the near infrared region is rather low, about 0.66 for the clear sky, and for the cloudy sky higher and some times larger than 0.75. From this comparison, the difference in the total albedo for the clear and cloudy sky can be explained. As shown in Fig. 10 in the last section, clouds make the incident solar flux rich in visible region, then the total albedo becomes higher.

In recent years, extensive theoretical calculations based on the multiple scattering radiative transfer model for the snow albedo using the delta-Eddington approximation (Joseph et al., 1976) were made by Wiscombe and Warren, and Choudhury and Chang groups. Most of the results were similar, and showed large spectral dependence, large dependence on the snow grain size in the near infrared region and large dependence on the contamination in the visible region.

The present measured albedo is compared to these albedo models. In order to compare in wide spectral regions, an integration has to be made as

$$
a_{\Delta \lambda}=\frac{\int_{\Delta \lambda} a_{s}(\lambda) \cdot G(\lambda) d \lambda}{\int_{\Delta \lambda} G(\lambda) d \lambda},
$$

where $a_{s}(\lambda)$ is the spectral albedo, $G(\lambda)$ is a spectral global radiation and $a_{\Delta \lambda}$ is an integrated albedo for the wavelength region $\Delta \lambda$. The spectral albedo by Wiscombe and Warren (1980) for the direct beam, grain size $r=100 \mu \mathrm{m}$ and solar elevation 30 degrees, and the spectral distribution of global radiation by Choudhury and Chang (1981) for the Antarctic coastal region are used. Thus the incident flux is not strictly applicable to the inland station as Mizuho and the spectral effect of albedo on the incident flux is not included in their calculation. Results are listed in Table 1 and they are in good accordance with the present measured results. The high albedo in the visible region of the present result, being in accordance with the pure snow model, suggests that the snow has negligible effect of contamination at this site. The observational site at Mizuho Station is more than $70 \mathrm{~m}$ upwind the station facilities. It was reported by Fujii and Ohata (1982) that the particle contamination of the snow near the surface at Mizuho was in the order of $0.02 \mathrm{ppmw}$, which is a negligible amount from the point of albedo (Warren and Wiscombe, 1980).

The previous work by Liljequist (1956) at Maudheim showed a high albedo in the visible region as about 0.97 . On the contrary, Kuhn and Siogas (1978) measured the visible albedo 
Table 1 Comparison of integrated albedo, measured at Mizuho Station and calculated from the theoretical model by Wiscombe and Warren (1980). Spectral distribution of the incident solar flux at the surface by Choudhury and Chang (1981) was used in the integration. For the clear sky.

\begin{tabular}{cccc}
\hline & $\begin{array}{c}\text { VIS } \\
(305-695 \mathrm{~nm})\end{array}$ & $\begin{array}{c}\text { IR } \\
(695-2800 \mathrm{~nm})\end{array}$ & $\begin{array}{c}\text { Total } \\
(305-2800 \mathrm{~nm})\end{array}$ \\
\hline $\begin{array}{c}\text { Calculated } \\
\left(h=30^{\circ}\right)\end{array}$ & 0.976 & 0.685 & 0.828 \\
$(r=100 \mathrm{um})$ & $0.96-0.98$ & $0.65-0.70$ & $0.80-0.82$ \\
\hline $\begin{array}{l}\text { Measured } \\
(\text { average })\end{array}$ & $(0.963 \pm 0.037)$ & $(0.655 \pm 0.018)$ & $(0.805 \pm 0.009)$ \\
\hline
\end{tabular}

at the South Pole to be 0.85 to 0.92 , which was assumed by Warren and Wiscombe (1980) to be contaminated by $10 \mathrm{ppmw}$ of soil dust or $0.1 \mathrm{ppmw}$ carbon soot comparing to their model albedo. From the present result, it is certified that the visible albedo is higher than 0.95 for the clean pure snow which is normally seen in the Antarctic snow field without artificial contamination.

\section{Incident angle dependence of albedo}

The solar zenith angle dependence of albedo under the clear sky is shown in Fig. 12. Different from measurements at the South Pole, it is difficult to derive a pure zenith angle dependence at Mizuho from diurnal measurements, because the azimuth angle dependence also affects the result. There is a large difference between several groups of the results of the measurement and distinguished by the observational periods, expressed by the different type of points. One set for the early stage of the measurement (February, March) and for

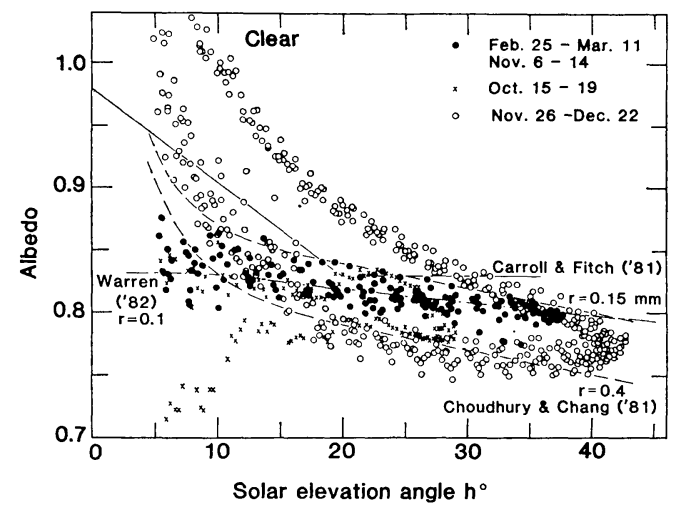

Fig. 12 Clear sky albedo as a function of solar elevation angle $h$. Points show measurements on 30 minutes average distinguished by the observational period.
November 6 to 14 , shows very calm dependence on the solar elevation (solid circle). Another set for November 26 to December 22 shows a steep dependence on the solar elevation and has a different albedo before and after noon (we call this type steep dependence; white circle). However, the tendency that the high albedo at the low solar height is the same for both sets. One set from October 15 to 19 shows an irregular dependence on the solar elevation (cross).

The dependence of the albedo on the solar elevation angle can be explained as follows; light incident near the horizon tends to be scattered by the particle near the surface and is liable to escape from the snowpack without being absorbed compared to the light incident near the normal and goes into deeper. The situation will be more enhanced by the asymmetry of scattering phase function (Warren, 1982). As for the global radiation this dependence is weakened by the diffuse component, because the contribution of diffuse flux becomes large at low solar elevation as seen in section 4 .

The differences of the measured dependence are due to variations of the microscopic scale snow surface condition, i.e., metamorphosis and macroscopic scale surface feature, but it is difficult to separate the both effects. Normally around Mizuho Station, after fallen on the surface, snow particles yield no melting but undergo metamorphosis and the sintering of snow particles occurs and particles are no more independent grains (erosional surface; Narita, 1978; Fujii, 1979; Fujii, 1981). The albedo will show a steep dependence on the incident angle. As for the macroscopic scale, most of the surface consisted of large sastrugi after late autumn and did not disappear throughout the observation period.

There is a hysteresis of the albedo-incident angle curve for the steep dependence. Since the 
albedo is constantly higher in the morning than afternoon in this case, a melting of snow particles in the afternoon can be supposed. However, there is no evidence of the melting. The hysteresis is caused by the tilt surface of large sastrugi and the striation of sastrugi field which lies parallel to the cyclonic wind direction, about 70 degrees from the north. When the azimuth is in the direction perpendicular to the sastrugi the albedo is lower than when the azimuth is in the direction parallel, on account of a difference in effective incident angle and a shadow made by sastrugi (Kuhn, 1974; Carroll and Fitch, 1981; Aida, 1982). A simple geometrical calculation by Carroll (1982) suggests that an albedo has both possibilities to be high and to be low with the increase of surface striations, depending on the relation between the solar zenith angle, surface tilt angle and azimuth direction.

In some term, for example between November 6 and 14, the surface was renewed by small particles by the drifting snow. Also, most of the steep sastrugies grown in the preceding months were smoothed out by drifting snow in this term, which was seen from the photographs taken in those days. The surface showed a calm dependence of the albedo on the incident angle. After these days, the deposited snow on the surface was again blown away and the hard (erosional) surface with steep sastrugi appeared. Though the measuring site was not in the socalled glazed surface, even in the erosional surface, glittering in the reflected radiation might increase and the steepness of the albedo-incident angle curve increased. However, we did not have a precise description of the snow surface itself, it is still left to be a speculation.

In order to confirm these situations, we tried to flatten the sastrugies and soften the surface in the next January with a shovel. Fig. 13 shows this result. Before flattening the surface (open circle) the incident angle dependence was similar to that for the steep dependence shown in Fig. 12. After flattening (solid circle), a drastic change had occurred and the dependence became very calm, and at some part rather opposite. Some differences in the albedo before noon and after noon were still remained, and they might be caused by the surface inclination of the large mound type sastrugi lied in the near field.

The solar zenith angle dependence of the clear sky albedo is compared to that of model calcu-

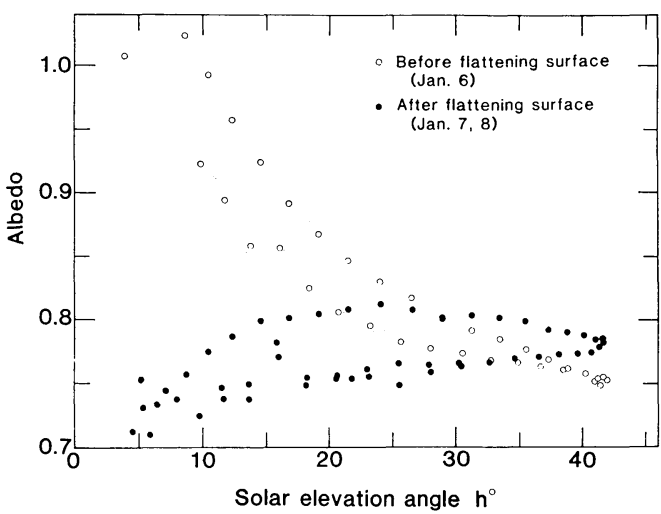

Fig. 13 Same as Fig. 12, but for the variation along with the artificial modification of the snow surface condition.

lations. The dependence by Choudhury and Chang (1981) for the faced surface grains of grain radius 0.15 and $0.4 \mathrm{~mm}$, respectively are plotted in Fig. 12. These curves have a rather strong dependence on the solar elevation angle and similar to the part of steep dependence of the present results. A large part of the points of the present measurements fall between the two curves. This fact suggests that the snow grain radius is in the order of $0.1-0.4 \mathrm{~mm}$. The model calculation by Wiscombe and Warren (Warren, 1982) for a grain radius $0.1 \mathrm{~mm}$, shows a much weaker dependence on the solar elevation angle (Fig. 12). This curve resembles the calm dependence of the present work.

The albedo measured by Carroll and Fitch (1981) is also shown in Fig. 12, which has a strong dependence on the solar elevation angle. At the low solar elevation, this curve seems to be in accordance with the steep dependence of the present results.

The argument as for the incident angle dependence made between Warren and Wiscombe (1981), and Choudhury (1982) may partly be dissolved. From the comparison made with the present measurements, it has become apparent that the theoretical model using a phase function for a spherical particle (without "surface reflection") can explain the measured natural snow albedo for the renewed snow surface with fine-grained rounded particles, However, the model can not explain the snow albedo when surface grains become more faced as mentioned by Choudhury (1981) or when the sintering of particles occurred, and surface specular reflection-single scattering contribution-comes more 
pronounced. In the latter case, a hypothesis of "fine-grained snow" does not hold any longer and it is difficult to be approximated by the spherical particle phase function. The latter case - erosional surface - is rather normal at Mizuho as reported by Fujii (1981).

The solar elevation angle dependence of albedo under the overcast sky with the thickest cloud is shown in Fig. 14. The scattering of points is much smaller in this figure compared with Fig. 12. This is because the incident flux is diffuse and has nothing to do with the direction of the surface irregularity. Though the slope is gentle, the albedo under the overcast sky has also some dependence to be high at low solar elevation. As for the incident angle, there should be no change according to the variation in solar zenith angle if the incident flux is perfectly diffuse. This solar angle dependence is explained from the alternation in spectral component, shown in Fig. 10. When the solar elevation comes low, the incident flux becomes rich in the visible component which has high albedo and the total albedo becomes high.

The relation between the solar elevation angle dependence of albedo under the clear sky and that under the overcast sky is not so simple. The albedo for the diffuse flux is some weighted mean of the albedo for the direct flux which must be similar to Fig. 12. It was said that the albedo for the direct radiation and albedo for the isotropic scattered diffuse radiation were same at $h \approx 40^{\circ}$ by Wiscombe and Warren (1980). If there was no spectral effect or in the case of the monochromatic radiation, the clear sky albedo would be higher than the cloudy sky albedo at $h<40^{\circ}$. However, it is not the case for the total albedo on account of the spectral effect.

The cloudy sky albedo is also compared in Fig. 14 with other results. The measured dependence by Carroll and Fitch (1981) at the South Pole resembles the present results fairly well, however, the albedo in the region of $h>$ $18^{\circ}$ is little lower than the present albedo. This is because the present albedos are only those under the thick cloud (As: 10/10), while the results by Carroll and Fitch were obtained for those under several kinds of clouds. Calculations by Choudhury and Chang (1981) for the fractional cloud cover 10/10 show the different tendency that the albedo becomes low when the solar elevation is low. This tendency is caused by the different dependence of spectral compo-

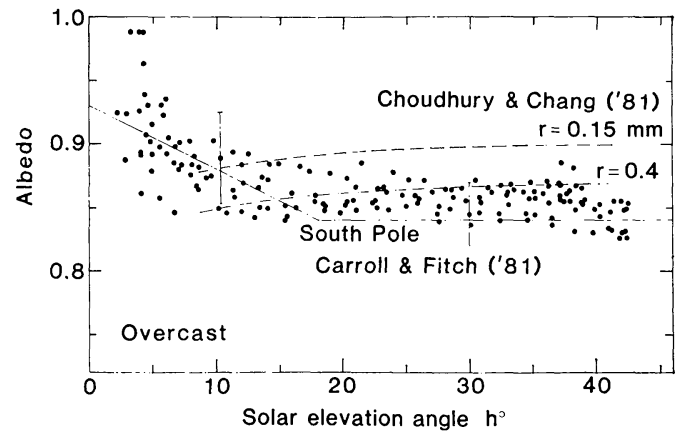

Fig. 14 Cloudy sky albedo as a function of solar elevation angle $h$.

nent of global flux against the solar elevation angle as shown in Fig. 10 by crosses.

Though the variation of albedo is only a few percent, it would amount to a large portion of net absorbed radiation because of the high albedo about $80 \%$, and it might greatly affect the radiation balance or metamorphosis of the snow near the surface.

\section{Concluding remarks}

The global radiation at Mizuho Station is large compared to that at the normal mid latitude station at the same solar zenith angle. This is because the atmospheric transmittance is high on account of small amount of atmospheric molecules, aerosols and water vapor. Moreover, the diffuse component is large owing to the high surface albedo through the multiple reflection between the snow surface and atmospheric layer. Most of the diffuse radiation is composed of the Rayleigh scattering, which would increase more than twice when the surface albedo is increased from 0 to $80 \%$. The depletion of the global radiation by clouds appears to be small also on account of the high surface albedo through the multiple reflection between the snow surface and cloud layer, especially in the visible flux.

The average value of snow albedo for the clear sky is $0.81 \pm 0.01$ in the total wavelength region of the solar flux. In the visible region, the albedo is higher than $0.95(0.96 \pm 0.04)$, and in the near infrared region, it is $0.66 \pm 0.02$ under the clear sky. The solar zenith angle dependence of the albedo is various, very steep for the hard erosional surface and calm for the soft depositional surface composed of fine-grained particles, however, in general the albedo becomes high with the increase of solar zenith angle. 
Sastrugi, oriented to a particular direction by the wind, makes this dependence much irregular. Clouds raise the total albedo sometimes to higher than 0.85 by altering the spectral distribution of the incident solar flux.

The measured albedos in the total, visible and near infrared spectral region show a fairly good agreements to the calculated albedos obtained by Wiscombe and Warren (1980) in the case of average, however, uncertainties still remain in the zenith angle dependence of albedo. More works should be made in the future to correspond the spectral albedo and the zenith angle dependence in detail to the actual snow surface conditions (shape and size of the particles, surface construction, roughness), both experimentally and theoretically.

Also works should be made to clarify the relation between the radiation field and cloud and drifting snow.

\section{Acknowledgements}

The author wishes to express his sincere thanks to the members of the POLEX-South group of Japanese Antarctic Research Expedition for their support to the observations. The author is also grateful to Drs. N. Ishikawa of the Institute of Low Temperature Science, Hokkaido Univ., and T. Nakajima of Tohoku Univ. for their valuable discussions and comments. Special thanks are due to Profs. M. Tanaka, Tohoku Univ. and S. Kawaguchi, National Institute of Polar Research for providing the opportunity for this research. The author is indebted to Ms. K. Sukeno and S. Nishikawa for their assistance in preparing the manuscript.

The data reduction was made with the aid of HITAC M-160-II Computer of National Institute of Polar Research.

\section{References}

Aida, M., 1982: Urban albedo as a function of the urban structure-A model experiment. Boundary Layer Meteor., 23, 405-413.

Carroll, J. J., 1982: The effect of surface straiations on the absorption of shortwave radiation. J. Geophys. Res., 87, 9647-9652.

elevation and cloudiness of snow albedo at the South Pole. J. Geophys. Res., 86, 5271-5276.

Choudhury, B., 1981: A note on the solar elevation dependence of clear-sky snow albedo. Cold Regions Sci. Tech., 5, 173-176.

, 1982: Reply to comment by Warren and Wiscombe on "Radiative properties of snow for clear sky solar radiation." Cold Region Sci. Tech., 5, 275-276.

and A.T.C. Chang, 1981: The albedo of snow for partially cloudy skies. Boundary Layer Meteor., 20, 371-389.

Coulson, K. L., 1968: Effect of surface reflection on the angular and spectral distribution of skylight. J. Atmos. Sci., 25, 759-770.

, 1975: Solar and terrestrial radiation. Academic Press, New York, $322 \mathrm{p}$.

Dalrymple, P.C., 1966: A physical climatology of the Antarctic plateau. Studies in Antarctic Meteorology, ed. by M. J. Rubin. Washington, D.C., Amer. Geophys. Union, 195-231 (Antarct. Res. Ser., vol. 9).

Fröhlich, C. and G. E. Shaw, 1980: New determination of Rayleigh scattering in the terrestrial atmosphere. Appl. opt., 19, 1773-1775.

Fujii, Y., 1979: Sublimation and condensation at the ice sheet surface. Antarct. Rec., 67, 51-63. , 1981: Formation of surface snow layer at Mizuho Station, Antarctica. Mem. Natl Inst. Polar Res. Special Issue, 19, 280-296.

- and T. Ohata, 1982: Possible causes of the variation in microparticle concentration in an ice core from Mizuho Station, Antarctica. Annals of Glaciology, 3, 107-112.

Grenfell, T. C. and G. A. Maykut, 1977: The optical properties of ice and snow in the Arctic basin. J. Glaciology, 18, 445-463.

Hanson, K. J., 1960: Radiation measurements on the Antarctic snowfield, a preliminary report. $J$. Geophys. Res., 65, 935-946.

Ishikawa, N., S. Kobayashi, T. Ohata and S. Kawaguchi, 1982: Some radiation properties at $\mathrm{Mi}-$ zuho Station, East Antarctica, in 1980. Mem. Natl Inst. Polar Res. Special Issue, 24, 19-31.

Joseph, J. H., W. J. Wiscombe and J. A. Wienman, 1976: The delta-Eddington approximation for radiative flux transfer. J. Atmos. Sci., 33, 24522459.

Kawaguchi, S. and H. Sasaki, 1975: Solar radiation balance at Mizuho Camp, East Antarctica. $A n$ tarct. Rec., 54, 34-41.

Kondratyev, K. Ya., 1969: Radiation in the Atmosphere. New York, Academic Press, $912 \mathrm{p}$ (International Geophys. Ser., vol. 12).

Kuhn, M., 1974: Anisotropic reflection from sastrugi fields. Antarct. J. U.S., 9, 123-125.

and L. Siogas, 1978: Spectroscopic studies at McMurdo, South Pole, and Siple Stations during the austral summer 1977-78. Antarct. J.U. S., 13, 178-179.

, L. S. Kundla and L. A. Streschein, 1977: The radiation budget at Plateau Station, Antarctica, 1966-1967. Meteorological Studies at Plateau Station, Antarctica. ed. by J. A. Businger. Washington, D.C., Amer. Gophys. Union, 41-73 (Antarct. Res. Ser., vol. 25). 
Kusunoki, K., 1981: Japanese Polar Experiment (POLEX) in the Antarctic in 1978-1982. Mem. Natl Inst. Polar Res. Special Issue, 19, 1-7.

Liljequist, G. H., 1956: Energy exchange of an antarctic snow field. Norwegian-British-Swedish Antarctic Expedition, 1949-1952. Scientific Results, vol. II, Part 1A. Oslo, Norsk Polarinstitut, $109 \mathrm{p}$.

Liou, K., 1976: On the absorption, reflection and transmission of solar radiation in cloudy atmospheres. J. Atmos. Sci., 33, 798-805.

Mae, S., M. Wada and T. Yamanouchi, 1981: The system of measurements of radiation and micrometeorological elements at Mizuho Station, East Antarctica: Installation and performance. $A n$ tarct. Rec., ' $\mathbf{1 1}, 44-57$.

Narita, H., 1978: Controlling factors of drifting snow. Mem. Natl Inst. Polar Res. Spec. Issue, 7, 81-92.

Paltridge, G. W. and C. M. R. Platt, 1976: Radiative Processes in Meteorology and Climatology. New York, Elsevier, $318 \mathrm{p}$ (Developments in Atmospheric Science, vol. 5).

Rusin, N.P., 1964: Meteorological and Raidational Regime of Antarctica. Jerusalem, Israel Program for Scientific Translations, $380 \mathrm{p}$.

Thekaekara, M. P. and A. J. Drummond, 1971: Standard values of the solar constant and its spectral components. Nature Phys. Sci., 229, 6-9.

Warren, S. G., 1982: Optical properties of snow. Rev. of Geophys. Space Phys., 20, 67-89.

and W. J. Wiscombe, 1980: A model for the spectral albedo of snow. II: Snow containing atmospheric aerosols. J. Atmos. Sci., 37, 27342745.

and 1981: Comment on "Radiative properties of snow for clear sky solar radiation". Cold Regions Sci. Tech., 5, 177-180. and $\longrightarrow$, 1982: Spectral radiation modeling for the Antarctic plateau: Effects of clouds, ozone and $\mathrm{CO}_{2}$ on the radiation budget (abstract). Annals of Glaciology, 3, 356.

Weller, G. E., 1967: Radiation fluxes over an Antarctic ice surface, Mawson, 1961-1962. ANARE Sci. Rep., Ser. A (IV) Glaciology, 96, 106 p.

Wendler, G., F. D. Eaton and T. Ohtake, 1981: Multiple reflection effects on irradiance in the presence of Arctic stratus clouds. J. Geophys. Res., 86, 2049-2057.

Wiscombe, W. J., 1975: Solar radiation calculations for Arctic summer stratus conditions. Climate of the Arctic, ed. by G. Weller and S. A. Bowling, Fairbanks, University of Alaska, 245-254. and S. G. Warren, 1980: A model for the spectral albedo of snow. I: Pure snow. J. Atmos. Sci., 37, 2712-2733.

Yamanouchi, T., 1982: Derivation of atmospheric turbidity at Mizuho Station, Antarctica from the broad-band solar radiation measurements. Mem. Natl Inst. Polar Res. Special Issue, 24, 1-12. and M. Wada, 1981: On the spectrometer measurements of column water vapor amount in the Antarctic atmosphere. Mem. Natl Inst. Polar Res. Special Issue, 19, 49-61.

- , S. Mae and S. Kawaguchi, 1981a: POLEX-South data, Part 1. Radiation data at Mizuho Station, Antarctica in 1979. JARE Data Rep., 61 (Meteorol. vol. 8), 350 p.

Tsukamura, 1981b: Measurements of radiation components at Mizuho Station, East Antarctica in 1979. Mem. Natl Inst. Polar Res. Special Issue, 19, 27-39. Kusunoki, 1982: The radiation budget at $\mathrm{Mi}$ zuho Station, Antarctica, 1979. Annals of Glaciology, 3, 327-332.

\title{
南極みずほ基地における入射太陽光と雪面のアルベードの 太陽天頂角や雲による変化
}

\author{
山 内 恭 \\ 国立極地研究所
}

1979年から1981年にわたり，POLEX-South（極域気水圏観測）計画の下に，東南極みず汪基地の雪面上に拉 いて入射および反射太陽光の波長別観測を行った。全天日射およびアルベードの 1 日の，あるいは日々，季節に よる変化を, 特に日射とアルベードとの相互作用に注目し，2つの波長域あるいは太陽天頂角, 雲量等に対して 整理した。

全天日射量は通常の中緯度帯の観測点での值に比べ，同じ太陽高度では極めて大きい。これは大気分子やエア ロゾル，水蒸気が少いために大気の透過率が高いためであり，透過率は夏期間の月平均值で0.75から0.80であっ た。さらに散乱日射量も，大部分はレイリー散乱成分だが，雪面と大気層との間の多重反射により大きく，アル 
ベード 0\%の所に比べ約 2 倍になっている。雲が全天日射を減らす度合は，やはり雪面と雲との間の多重反射の ために小さい。地吹雪の全天日射に対する影響についても議論した。

雪面のアルベードは，晴天下，日射の全波長域で日平均約 0.8 , また可視域では 0.95 以上，近赤外域で約 0.66 である。曇天下のアルベードは, 入射光の波長分布の違いのため, 晴天下の值より高く, 日平均でしばしば0.85 を越えている。アルベードの太陽高度依存性は, 雪表面の微細構造やマクロな雪面形態に依存して様々であった が，多くは太陽高度が下るとアルベードは上る傾向にあった。アルベードの測定值を，放射伝達モデルによる計 算值と比較したが，平均としては良い一致が見られた。 